\title{
PEMODELAN TARIKAN PERJALANAN KAWASAN PERDAGANGAN JASA SKALA KECIL DI JALAN SUKUN RAYA BANYUMANIK
}

\section{TRIP ATTRACTION MODEL OF A SMALL COMMERCIAL AND SERVICES AREA AT SUKUN RAYA BANYUMANIK ROAD}

\author{
Yudi Basuki, Sri Rahayu, Novia Windri Rahmawati \\ Departemen Perencanaan Wilayah dan Kota, Universitas Diponegoro
}

\section{Info Artikel:}

- Artikel Masuk: 7 Mei 2019

\begin{abstract}
ABSTRAK
Kecamatan Banyumanik tumbuh dan berkembang mengikuti peningkatan kebutuhan penduduk. Jalan Sukun Raya merupakan jalan yang biasa digunakan oleh penduduk di Kelurahan Srondol Wetan menuju ke Jalan Setiabudi maupun sebaliknya. Koridor Jalan Sukun Raya merupakan salah satu jalan lokal yang berada di Kecamatan Banyumanik masuk dan keluar menuju Jalan Setiabudi, dimana penggunaan lahan di koridor ini merupakan kawasan perdagangan, permukiman. Penggunaan lahan pada koridor jalan tersebut adalah kawasan perdagangan dan jasa. Berdasarkan permasalahan tersebut maka perlu dilakukan pemodelan tarikan perjalanan. Dalam hal ini, tarikan perjalanan dibutuhkan dalam mempertimbangkan dampak pembangunan yang ada, seperti pada sub pusat kawasan perdagangan dan jasa, perumahan dan perkantoran. Tujuan artikel ini adalah membuat pemodelan tarikan perjalanan. Pemodelan tarikan perjalanan menggunakan analisis regresi linier berganda dengan metode stepwise pada kawasan perdagangan dan jasa skala lingkungan di Jalan Sukun Raya Kecamatan Banyumanik yang merupakan kawasan sub pusat pelayanan dari Kota Semarang. Korelasi dan analisis regresi linier berganda ini dilakukan berdasarkan data yang diperoleh dari hasil survei. Pengumpulan data Jalan Sukun Raya pada waktu puncak, dilakukan dengan kegiatan observasi lapangan dan wawancara pada narasumber yang sudah ditetapkan. Hasil penelitian menunjukkan bahwa variabel omset penjualan menjadi variabel yang paling berpengaruh pada tarikan perjalanan yang ditunjukkan dalam persamaan $\mathrm{Y}=0,352+4,998 \mathrm{E}-7 \mathrm{X}$. Model yang dihasilkan berguna untuk memperkirakan tarikan perjalanan pada kawasan perdagangan dan jasa skala kecil.
\end{abstract}

Kata Kunci: pemodelan tarikan perjalanan, regresi linier berganda, perdagangan dan jasa

\section{ABSTRACT}

Banyumanik sub-district grows and develops cause by increasing in population. Jalan Sukun Raya is a road commonly used by residents in Srondol Wetan Village to Jalan Setiabudi and vice versa. Sukun Raya Road Corridor is one of the local roads in Banyumanik Subdistrict. The land use in this corridor is a commercial and service area, and settlement. Land use in the road corridor is a commercial and service area. Based on these problems, it is necessary to do trip attraction modeling. In this case, trip attraction is needed in considering the impact of existing development, such as in the sub-center of the commercial and services area, housing and offices. The aims of this article to develop trip attraction model. Trip attraction modeling uses multiple linear regression analysis with the stepwise method on the commercial and service area and small scale on Jalan Sukun Raya, Banyumanik Subdistrict which is a sub-service area of the city of Semarang. Correlation and multiple linear regression analysis done based on data obtained from survey results. Data collection on Jalan Sukun Raya at peak times was carried out with field observations and interviews with established resource persons. The results showed that the sales income variable became the most influential variable on the trip attraction shown in the equation $Y=0.352+4.998 \mathrm{E}-7 \mathrm{X}_{4}$. The resulting model is useful for estimating trip attraction in small-scale commercial and service areas.

Keywords: trip attraction modeling, multiple linear regression, commercial and service areas 


\section{PENDAHULUAN}

Persyaratan yang perlu dipenuhi dalam proses perencanaan transportasi adalah pemodelan transportasi atau estimasi lalu lintas yang dihasilkan oleh penggunaan lahan tertentu (Zavatterd et al, 1981). Pemodelan transportasi merupakan suatu konsep yang menerapkan pembangunan pada sistem prasarana transportasi, sistem pergerakan, dan peramalan kebutuhan akan transportasi untuk merencanakan pergerakan dengan efisien (Tamin, 2000). Daya tarik perjalanan sangat berhubungan terhadap pergerakan arus lalu lintas dengan aktivitas penggunaan lahan. Salah satu ragam aktivitas manusia yang dimana terjadi pergerakan untuk memenuhi kebutuhan ekonomi yaitu perjalanan belanja. Faktor lainnya yang mempengaruhi tingkat tarikan perjalanan adalah guna lahan perdagangan dan jasa, pemusatan zona kerja, dan kepadatan bangungan, faktor-faktor tersebut membentuk pemusatan kota yang baru (Jayasinghe et al., 2017). Pergerakan berbelanja sangat penting untuk memenuhi kebutuhan sehari-hari (Abulebu et al, 2018).

Sejarah pemodelan perjalanan belanja, dimulai dengan model gravitasi, yang mengasumsikan bahwa probabilitasnya untuk memilih tujuan untuk belanja berkolerasi dengan jarak ke tujuan (Haynes et al, 1984). Daya tarik perjalanan ditentukan berdasarkan dua jenis pusat perbelanjaan: satu dengan skala menengah dan pusat perbelanjaan skala kecil (Sasidhar et al., 2016). Berdasarkan jenisnya, pusat perbelanjaan skala kecil memiliki rata-rata tingkat tarikan perjalanannya lebih tinggi dibandingkan dengan pusat perbelanjaan skala menengah. Hal ini menyatakan bahwa tingginya rata-rata tingkat tarikan perjalanan pada pusat perbelanjaan skala kecil dipengaruhi oleh ukuran skala dari pusat perbelanjaan dan luasan pusat perbelanjaan. Selain itu luasan area lantai, kapasitas parkir, total karyawan dan komoditas terjual adalah faktor yang dominan dalam mempengaruhi daya tarik perjalanan (George et al., 2007). Sejarah dalam pemodelan perjalanan belanja dengan menggunakan model tarikan perjalanan yang mengasumsikan probabilitas untuk memilih tujuan yang memiliki korelasi dengan jarak asal ke tempat tujuan (Kristoffersson et al, 2018). Pemodelan tarikan perjalanan dapat digunakan untuk memperkirakan permintaan perjalanan untuk mendukung pembangunan berkelanjutan dengan menghasilkan perkiraan dampak lalu lintas dan penilaian perjalanan di masa depan (Currans, 2017). Pemodelan yang disesuaikan dengan skala kawasannya akan bermanfaat dalam menemukan korelasi antara rata-rata jumlah tarikan perjalanan dengan klasifikasi pusat perbelanjaan berdasarkan pada luasannya. Sehingga pemodelan tarikan perjalanan pada kawasan perdagangan dan jasa di koridor jalan raya perlukan selain untuk melihat memprediksi tarikan perjalanan di masa mendatang juga untuk melihat dampaknya terhadap lalu lintas jalan (Datta et al., 1998).

Semarang dengan pertumbuhan kawasan pinggiran melahirkan sub pusat pelayanan yang berupa kawasan perdagangan dengan skala pelayanan lokal. Kecamatan Banyumanik merupakan salah satu wilayah pinggiran yang berkembang pesat di Kota Semarang. Kecamatan Banyumanik merupakan wilayah penyangga bagi Kota Semarang yang berfungsi sebagai penampung kegiatan dari aktivitas yang terjadi berlebihan di pusat kota. Kecamatan Banyumanik perkembangannya dapat dilihat dengan adanya peningkatan jumlah penduduk dengan rata-rata sebesar 2,86\% dibandingkan dengan kondisi peningkatan jumlah penduduk rata-rata Kota Semarang sebesar 1,65\% tahun 2016-2017 (BPS, 2018). Perkembangan Kecamatan Banyumanik dapat dilihat dari adanya pertumbuhan kawasan permukiman yang dipengaruhi dari adanya pengaruh kawasan pendidikan dari Kecamatan Tembalang, hal tersebut menyebabkan pertumbuhan jumlah penduduk terus meningkat.

Kecamatan Banyumanik juga merupakan entrance point Kota Semarang dari arah selatan, yang memungkinkan banyaknya kendaraan bermotor melintasi daerah tersebut, yang salah satunya pada persimpangan Jalan Sukun Raya dan Jalan Karangrejo yang berkembangan menjadi sub pusat pelayanan. Penggunaan lahan di Kecamatan Banyumanik berkembang mengikuti kebutuhan dan aktivitas yang ada di kawasan tersebut. Penggunaan lahan pada Jalan Sukun Raya di Kecamatan Banyumanik saat ini sebagai kawasan retil yang diantaranya terdapat Super Indo, rumah makan, dan lain-lain. Kawasan perdagangan dan jasa tersebut mempunyai potensi yang dapat meningkatkan pendapatan penduduk lokal. Masalah yang ada pada kawasan perdagangan dan jasa tersebut keterbatasan lahan parkir bagi pengunjung atau pembeli yang 
Basuki, Rahayu, Rahmawati/ Jurnal Pembangunan Wilayah dan Kota, Vol. 16, No. 1, 2020, 51-60

Doi: 10.14710/pwk.v16i1.23025

datang ke tempat tersebut. sehingga kawasan tersebut pada waktu tertentu terjadi pemadatan arus lalu lintas dikarenakan, menurunnya kapasitas jalan.

Penelitian sebelumnya telah memberikan bukti bahwa pengembangan kawasan perdagangan dan jasa memiliki dampak lalu lintas yang besar pada jaringan jalan, khususnya di kota-kota yang sudah padat (Yam et al., 2000). Penelitian tarikan perjalanan di Jalan Sukun Raya memiliki landasan literatur dari penelitian yang sudah pernah dilakukan. Dalam penelitian ini, variabel penelitian dibentuk dari beberapa teori yang berhubungan dengan pemodelan tarikan perjalanan terhadap kawasan perdagangan dan jasa. Variabel yang digunakan merupakan variabel-variabel yang paling berpengaruh dan sering digunakan dari penelitian sebelumnya. Variabel tersebut untuk memprediksi tarikan perjalanan yang selanjutnya akan dianalisis menggunakan yaitu regresi linier berganda untuk menemukan model dari tarikan perjalanan perdagangan dan jasa, dan penghitungan volume lalu lintas untuk mengetahui kondisi arus lalu lintas. Metode pengumpulan data berupa observasi lapangan dan wawancara.

Pada penelitian ini terdapat perbedaan dari penelitian yang sudah ada, yaitu tentang tarikan perjalanan untuk memprediksi perkembangan perdagangan dan jasa skala kecil pada sub pusat pelayanan. Penelitian pada kawasan perdagangan dan jasa skala kecil diperlukan untuk mengantisipasi permasalahan yang timbul karena perkembangannya.

\section{METODE PENELITIAN}

Untuk mengetahui model tarikan perjalanan terhadap kawasan perdagangan dan jasa dibutuhkan pengujian terhadap variabel-variabel berikut jumlah mobil pengunjung, jumlah pegawai, luas area toko, luas area parkir, dan omset dagang dengan menggunakan teknik statistic regresi linier berganda. Mayoritas pada penelitian sebelumnya pemodelan perjalanan dilakukan menggunakan regresi linier berganda untuk mengembangkan dan menguji sejumlah variabel dependen dan independen (Hutchinson, 1974). Secara umum bentuk model yang akan dihasilkan $Y=A+B_{1} X_{1}+B_{2} X_{2}+\ldots+B_{2} X_{2}$. dengan keterangan $Y, X_{1}, X_{2}, X_{3}$, dan $\mathrm{X}_{4}$ secara berturut-turut adalah jumlah kendaraan pengunjung (unit), jumlah pegawai toko (orang), luas area lantai toko $\left(\mathrm{m}^{2}\right)$, luas lahan parkir toko $\left(\mathrm{m}^{2}\right)$, dan omset penjualan dagang (rupiah). Model tarikan perjalanan pada penelitian ini akan dilakukan dengan menggunakan regresi linier berganda dengan metode stepwise untuk uji statistik yang dilakukan antara lain uji koefisien determinasi, uji F, analisis koefisien/interpretasi model, uji anova atau nilai t tabel dan uji heteroskedastisitas (Sugiyono, 2014).

Secara geografis, koridor Jalan Sukun Raya Banyumanik merupakan bagian dari wilayah administratif Kelurahan Srondol Wetan, Kecamatan Banyumanik Kota Semarang. Lokasi penelitian Jalan Sukun Raya Banyumanik merupakan tipe jalan 1 jalur, 2 lajur, 2 arah, untuk sketsa penampang Jalan Sukun Raya dapat dilihat pada Gambar 1

Tembok Bangunan Pizza Hut

Tembok Pagar SPBU

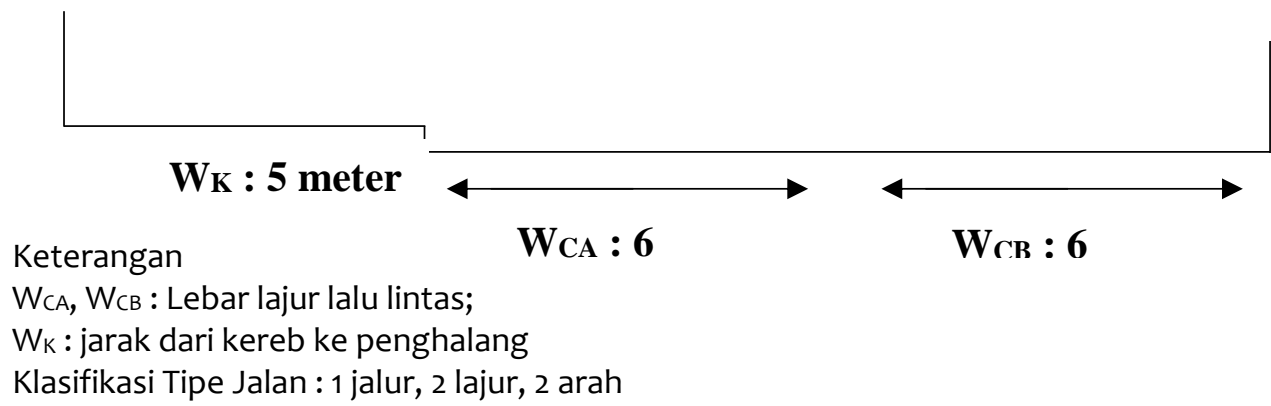

Sumber: Analisis Peneliti Berdasarkan Ketentuan MKJI 1997

Gambar 1. Penampang Jalan Sukun Raya Banyumanik 
Lokasi penelitian yang dipilih yaitu pada Jalan Sukun Raya Banyumanik berfokus pada penggunaan lahan perdagangan dan jasa sepanjang 200 meter dari entrance kawasan dari Jalan Setiabudi. Kawasan perdagangan dan jasa pada Jalan Sukun Raya Banyumanik dipilih sebagai lokasi penelitian karena kawasan ini berkembang menjadi sub pusat pelayanan..

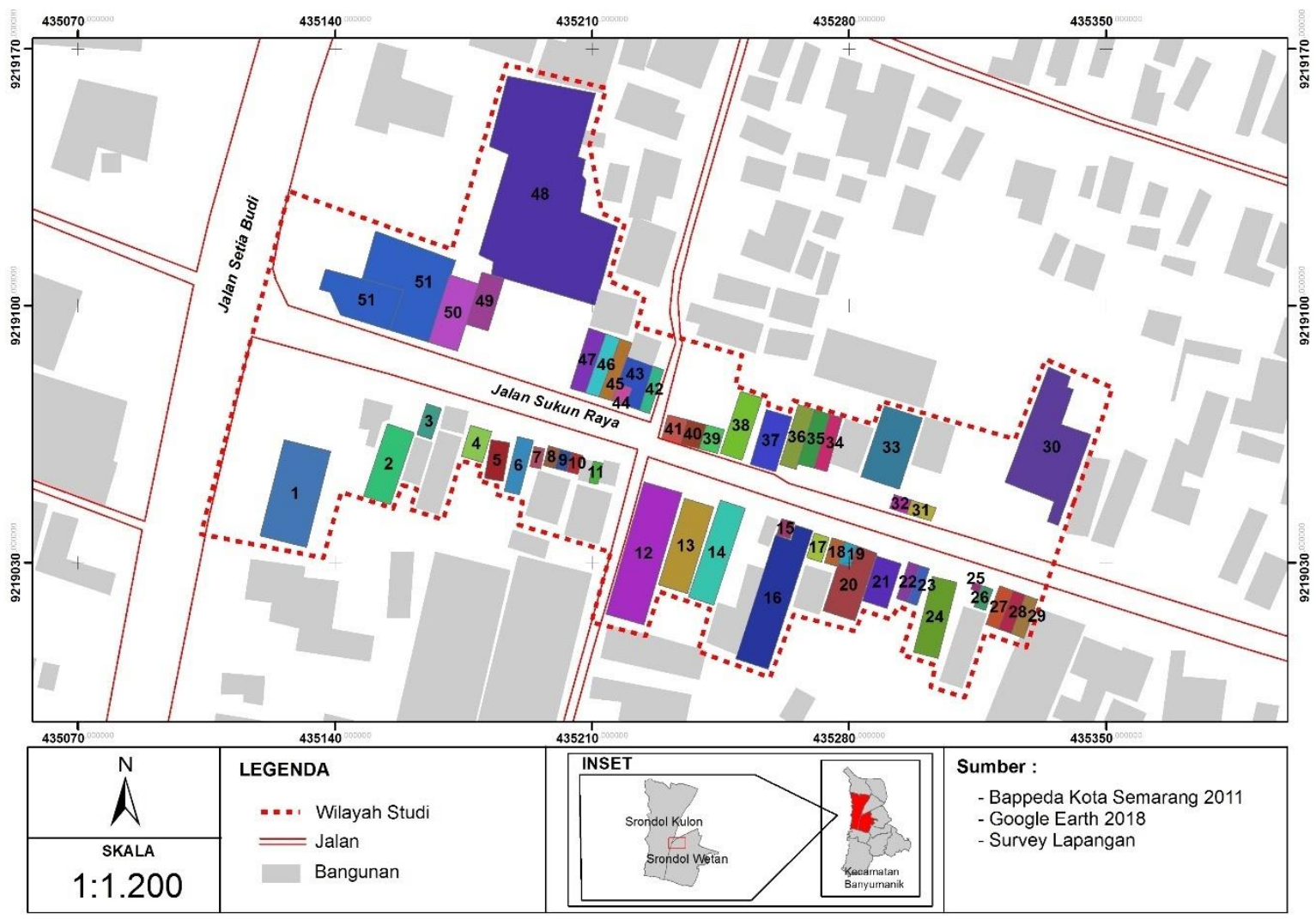

Sumber: Hasil Pemetaan Peneliti 2019

Gambar 2. Peta Sebaran Toko Pengamatan Pada Perdagangan dan Jasa

Tabel 1. Keterangan Nama 51 Perdagangan dan Jasa

\begin{tabular}{cccc}
\hline No & Nama Toko & No. & Nama Toko \\
\hline 1 & Pom Bensin & 26 & Bakso Kakap \\
2 & Indomaret (Minimarket) & 27 & Pulung Jaya \\
3 & Bengkel Yamaha & 28 & Warung (Ultra) \\
4 & SMS Shop & 29 & La Parfume \\
5 & Spesial Soto Ayam Pak No & 30 & Alfamidi \\
6 & Bakso Mr. Kribo & 31 & WM Padang \\
7 & Fajar Juice & 32 & Salon \\
8 & Royal Parfume & 33 & Indomaret \\
9 & Roemah Bantal & 34 & Lunpia Mini Mas Joko \\
10 & Tahu Baxo & 35 & WM Bu Windi \\
11 & Bengkel Siaga I & 36 & Lunpia Mini \\
\hline
\end{tabular}


Basuki, Rahayu, Rahmawati/ Jurnal Pembangunan Wilayah dan Kota, Vol. 16, No. 1, 2020, 51-60 Doi: $10.14710 /$ pwk.v16i1.23025

\begin{tabular}{lccc}
\hline No & Nama Toko & No. & Nama Toko \\
\hline 12 & Toko Surya Jaya & 37 & Mie Ayam Pak Ratno \\
13 & Leo Fashion & 38 & Jatimas \\
14 & WM Pak Yono & 39 & Warteg Citra Rasa \\
15 & Batik Smile & 40 & Booms Cutting Sticker \\
16 & Jatimas & 41 & Cetar Pet Shop \\
17 & Nasgor Pak Min Sentot & 42 & Forceum (Ban) \\
18 & Toko Cat Har Sumber Agung & 43 & Murah Jaya (Ban) \\
19 & Bengkel Sri Rezeki & 44 & Zeteex (Ban) \\
20 & Bengkel Suzuki & 45 & Manunggal Sell \\
21 & Bengkel Manusia & 46 & Lunpia Ganefo \\
22 & Toko Kerudung & 47 & Serabi Notosuman \\
23 & AA Elektronik & 48 & Superindo \\
24 & Batik Smile & 49 & Pastry Homemade \\
25 & Toko Daye & 50 & Bengkel Sukses Makmur \\
& & 51 & Pizza Hut \\
\hline
\end{tabular}

Sumber : Street View View 2019

\section{ANALISIS DAN HASIL DATA}

\subsection{Variabel Dependen}

Variabel dependen yang dipilih untuk pemodelan regresi linier berganda adalah jumlah mobil pengungjung (unit) yang tertarik terhadap lokasi penelitian yaitu kawasan perdagangan dan jasa pada Jalan Sukun Raya Banyumanik, Y = Jumlah Tarikan Total Mobil dan Motor Pengunjung (smp/jam) Variabel tersebut merupakan data penelitian yang diperoleh dari hasil observasi lapangan yang dilakukan pada waktu puncak kawasan perdagangan dan jasa selama 1 jam.

\subsection{Variabel Independen}

Variabel independen yang dipilih tercantum di bawah ini :

$$
\begin{array}{ll}
X_{1} & =\text { Jumlah pegawai toko (orang) } \\
X_{2} & =\text { Luas area lantai toko }\left(\mathrm{m}^{2}\right) \\
X_{3} & =\text { Luas lahan parkir toko }\left(\mathrm{m}^{2}\right) \\
X_{4} & =\text { Omset Dagang (rupiah) }
\end{array}
$$

Variabel independent yang dipilih dikumpulkan melalui wawancara kepada pengelola toko pada perdagangan dan jasa yang sudah ditetapkan, wawancara menggunakan form wawancara yang sudah dirancang dengan baik.

\subsection{Analisis Statistik Data}

\subsubsection{Analisis Model Tarikan Perjalanan}

Model tarikan perjalanan kawasan perdagangan dan jasa ditunjukkan pada tabel koefisien yang dimana jumlah tarikan perjalanan dapat dilihat oleh koefisien pembentuk dari persamaan model yang ditunjukkan pada tabel 2. 
Basuki, Rahayu, Rahmawati/ Jurnal Pembangunan Wilayah dan Kota, Vol. 16, No. 1, 2020, 51-60 Doi: $10.14710 /$ pwk.v16i1.23025

Tabel 2. Model Tarikan Perjalanan

\begin{tabular}{|c|c|c|c|c|c|c|}
\hline & \multirow[t]{2}{*}{ Model } & \multicolumn{2}{|c|}{ Unstandardized Coefficients } & \multirow{2}{*}{$\begin{array}{c}\text { Standardized } \\
\text { Coefficients } \\
\text { Beta }\end{array}$} & \multirow[t]{2}{*}{$\mathrm{t}$} & \multirow[t]{2}{*}{ Sig. } \\
\hline & & $\mathrm{B}$ & Std. Error & & & \\
\hline & Konstanta & .352 & 1.418 & & .248 & .805 \\
\hline 1 & $\mathrm{X}_{4}$ & $4.998 \mathrm{E}-7$ & .000 & .883 & 13.159 & .000 \\
\hline
\end{tabular}

Sumber: Hasil Analisis SPSS, 2019

Berdasarkan dari hasil analisis model tarikan perjalanan lalu lintas pada Jalan Sukun Raya Banyumanik, didapatkan dua model dengan masing-masing variabel yang berpengaruh. Pada model pertama, variabel independennya $\mathrm{X}_{4}$ (omset penjualan toko waktu puncak). Model regresi yang didapatkan yaitu $\mathrm{Y}=0,352+$ 4,998E-7 $\mathrm{X}_{4}$. Berdasarkan model persamaan regresi tersebut dapat disimpulkan bahwa variabel bebas yang menentukan besarnya tarikan perjalanan adalah variabel omset penjualan toko pada hari puncak $\left(\mathrm{X}_{4}\right)$. Besarnya koefisien regresi untuk variabel omset penjualan pada hari puncak sebesar 4,998E-7.

Penelitian tarikan perjalanan ke mal dengan metode regresi linier berganda memiliki persamaan $\mathrm{Y}=$ $167,17+\left(-1,0774 X_{2}\right)+\left(0,0031 X_{4}\right)($ Bali et al, 2017). Variabel yang keluar menjadi model berupa variabel luas tempat parkir untuk kendaraan roda dua, dan luas lantai mal. Persamaan tarikan tersebut pada variabel $\mathrm{X}_{2}$ yaitu tempat parkir untuk kendaraan roda dua bernilai negatif, yang artinya setiap ada pengurangan dari luas tempat parkir untuk kendaraan roda dua berkontribusi meningkatkan tarikan perjalanan ke mal.

Berdasarkan model tarikan perjalanan kendaraan pengunjung pada kawasan perdagangan dan jasa di Jalan Sukun Raya didapatkan persamaan $\mathrm{Y}=0,352+4,998 \mathrm{E}-7 \mathrm{X}_{4}$ untuk memprediksi tarikan perjalanan kawasan perdagangan pada koridor jalan. Pada model tarikan tersebut ditunjukkan variabel yang berpengaruh terhadap tarikan perjalanan kendaraan yaitu variabel omset penjualan toko pada waktu puncak. Persamaan yang didapatkan pada penelitian ini berbeda dengan model persamaan penelitian sebelumnya yang terletak pada variabel bebas yang keluar menjadi model. Karakteristik perdagangan dan jasa skala kecil di Jalan Sukun Raya tarikan perjalanannya tidak dipengaruhi oleh luas area toko, jumlah pegawai maupun luas lahan parkir, tetapi dari besaran omset penjualan yang didapatkan oleh masingmasing toko yang paling mempengaruhi tarikan perjalanan kendaraan pengunjung. Hal ini menunjukkan setiap jenis kawasan perdagangan dan jasa maupun pusat perbelanjaan memiliki faktor pengaruh perjalanan yang berbeda-beda.

\subsubsection{Analisis Koefisien Determinasi}

Analisis ini bertujuan untuk mengetahui pengaruh atau hubungan antara empat variabel independen $\left(X_{1}, X_{2}, X_{3}, X_{4}\right)$ terhadap variabel dependen $(Y)$ secara serentak. Koefisien ini nantinya memperlihatkan seberapa besar hubungan yang ada antara variabel independen dan variabel dependen. Nilai $R$ yang berkisar o sampai 1 , nilai $R$ yang semakin mendekati 1 berarti terdapat hubungan yang kuat antara variabel dependen dan independen, sebaliknya jika nilai R semakin mendekati o maka hubungan yang ada semakin lemah. Dari hasil analisis regresi linier berganda, terdapat output Model Summary Tabel 3.

Tabel 3. Koefisien Determinasi

\begin{tabular}{lllll}
\hline Model & $R$ & R Square & Adjusted R Square & Std. Error of the Estimate \\
\hline $1\left(\mathrm{X}_{4}\right)$ & 0,883 & 0,7579 & 0,775 & 9,350 \\
\hline \multicolumn{5}{l}{ Sumber: Hasil Analisis, 2019}
\end{tabular}

Pada tabel model summary diatas dapat diperoleh informasi mengenai besarnya pengaruh dari variabel independen terhadap variabel dependen dari setiap model yang dihasilkan. Pengaruh tersebut disimbolkan dengan $\mathrm{R}$ (korelasi). Seperti yang terlihat dalam tabel diatas pada kolom R di model 1 adalah 0,883 yang artinya antara variabel independen $\mathrm{X}_{4}$ (omset penjualan toko waktu puncak) memiliki hubungan yang sangat kuat terhadap variabel dependen yaitu tarikan volume kendaraan pengunjung (smp/jam). 
Pada penelitian yang sebelumnya yaitu pada titik-titik kawasan perdagangan dan jasa yang tersebar di kota-kota berukuran menengah di Kerala memiliki nilai Adjusted R Square sebesar 0,9997 dari hasil analisis regresi linier berganda (George et al., 2007). Nilai pada adjusted $R$ Square memiliki arti dimana kontribusi pengaruh variabel bebas terhadap tarikan perjalanan mobil pengunjung sebesar $99 \%$ sedangkan nilai pada $R$ Square diperoleh 0,9999 yang menunjukkan 99\% dari variasi dalam perjalanan dipengaruh oleh variabel jumlah karyawan dan variabel persentase kantor di simpul, sementara $1 \%$ dipengaruhi oleh faktor lain.

Berdasarkan hal tersebut dapat disimpulkan bahwa setiap variabel bebas yang dihasilkan dari model memiliki pengaruh yang berbeda-beda tergantung dari variabel dependen maupun dari karakteristik lokasi penelitian. Pada perdagangan dan jasa di Koridor Jalan Sukun Raya didapatkan dengan nilai R Square 0,757 yang menunjukkan tarikan perjalanan dipengaruhi variabel omset penjualan sebesar $75 \%$ sementara $25 \%$ dipengaruhi oleh faktor lain. Nilai R Square yang tinggi ini menunjukkan korelasi yang tinggi antara perjalanan yang diamati dan diprediksi maka model valid.

\subsubsection{Uji Statistik F}

Uji ini dilakukan untuk dapat mengetahui apakah variabel independen secara bersama-sama memiliki pengaruh siginifikan pada variabel dependen. Atau untuk dapat mengetahui apakah model regresi dapat digunakan untuk memprediksi variabel dependen atau tidak yang dijelaskan pada tabel 4 .

Tabel 4. Uji Statistik F

\begin{tabular}{lll}
\hline Model & $F$ & Sig. \\
\hline $\mathrm{X}_{4}$ & 173.169 & 0,000 \\
\hline
\end{tabular}

Dari uji ANOVA atau $F$ test, didapat $F$ hitung untuk model pertama didapatkan 173,169. Dengan menggunakan dengan tingkat siginifikansi 0,000. Oleh karena probabilitas 0,000 jauh lebih kecil dari 0,050, maka model regresi dapat dipakai untuk memprediksi tarikan perjalanan kendaraan. Variabel $\mathrm{X}_{4}$ dapat juga dikatakan sebagai variabel yang berpengaruh terhadap tarikan perjalanan kendaraan.

Pada penelitian yang sebelumnya pernah dilakukan yaitu pada titik-titik kawasan perdagangan dan jasa yang tersebar di kota-kota berukuran menengah di Kerala memiliki signifikansi nilai $\mathrm{F}$ sebesar 0,0083 yang dimana nilai signifikasinya lebih kecil dari 0,050 artinya adanya hubungan liniear antara semua variabel $x$ dengan variabel y (George et al., 2007). Signifikansi nilai $F$ pada model pertama sebesar 0,000 yang dimana nilai tersebut lebih kecil dari 0,50 artinya terdapat hubungan linier antara variabel omset penjualan penjualan toko waktu puncak terhadap tarikan perjalanan dari total kendaraan mobil dan motor (smp/jam) pengunjung.

\subsubsection{Uji Statistik t}

Uji statistik t ini digunakan untuk menguji signifikasi konstanta dan koefisien regresi. Hipotesis $\mathrm{Ho}=$ koefisien regresi dan konstanta tidak signifikan $\mathrm{H} 1=$ koefisien regresi dan konstanta signifikan

Pengambilan keputusan

- Berdasarkan statistik $t$ tabel Jika statistik t Hitung < statistik t Tabel $(2,012)$, maka $\mathrm{H}_{\mathrm{o}}$ diterima Jika statistik t Hitung > statistik t Tabel $(2,012)$, maka $\mathrm{H}_{\mathrm{o}}$ ditolak

- Berdasarkan probabilitas Jika probabilitas $>0,05$, maka $\mathrm{H}_{0}$ diterima Jika probabilitas $<0,05$, maka $\mathrm{H}_{0}$ ditolak Nilai t hitung dan $\mathrm{t}$ tabel dijelaskan pada tabel 5 . 
Tabel 5. Uji t Terhadap Nilai Konstanta Model Tarikan Perjalanan

\begin{tabular}{lllllll}
\hline \multicolumn{1}{c}{ Model } & \multicolumn{1}{c}{$\mathrm{B}$} & t hitung & $\mathrm{t}$ tabel & Sig. & \multicolumn{2}{c}{ Perbandingan } \\
\hline Model 1 & & & & & & \\
Konstanta & .352 & .248 & 2,012 & .805 & t hitung $<\mathrm{t}$ tabel & Sig. $>0.050$ \\
$\mathrm{X}_{4}$ & $4.998 \mathrm{E}-7$ & 13.159 & 2,012 & .000 & $\mathrm{t}$ hitung $>$ t tabel & Sig. $<0.050$ \\
\hline
\end{tabular}

Sumber: Hasil Analisis SPSS, 2019

\section{Keputusan pemilihan model}

Oleh karena statistik t Hitung > statistik t Tabel, serta nilai Sig. $<0,05$ maka $\mathrm{H}_{\mathrm{o}}$ ditolak artinya bahwa koefisien regresi dan konstanta benar-benar berpengaruh secara signifikan terhadap variabel tak bebas.

\subsubsection{Uji Heteroskedastisitas}

Dalam penelitian ini uji heteroskedastisitas merupakan uji yang menilai apakah terdapat ketidaksamaan varian dari residual untuk semua pengamatan pada model yang dihasilkan pada regresi linier berganda. Uji ini merupakan salah satu dari uji asumsi klasik yang perlu dilakukan pada analisis regresi linier. Pada bahasan uji ini hasilnya dapat dilihat melalui grafik scatterplots. Scatterplots terdiri dari pola titik-titik pada scatter plots regresi yang dijelaskan pada gambar 3 .

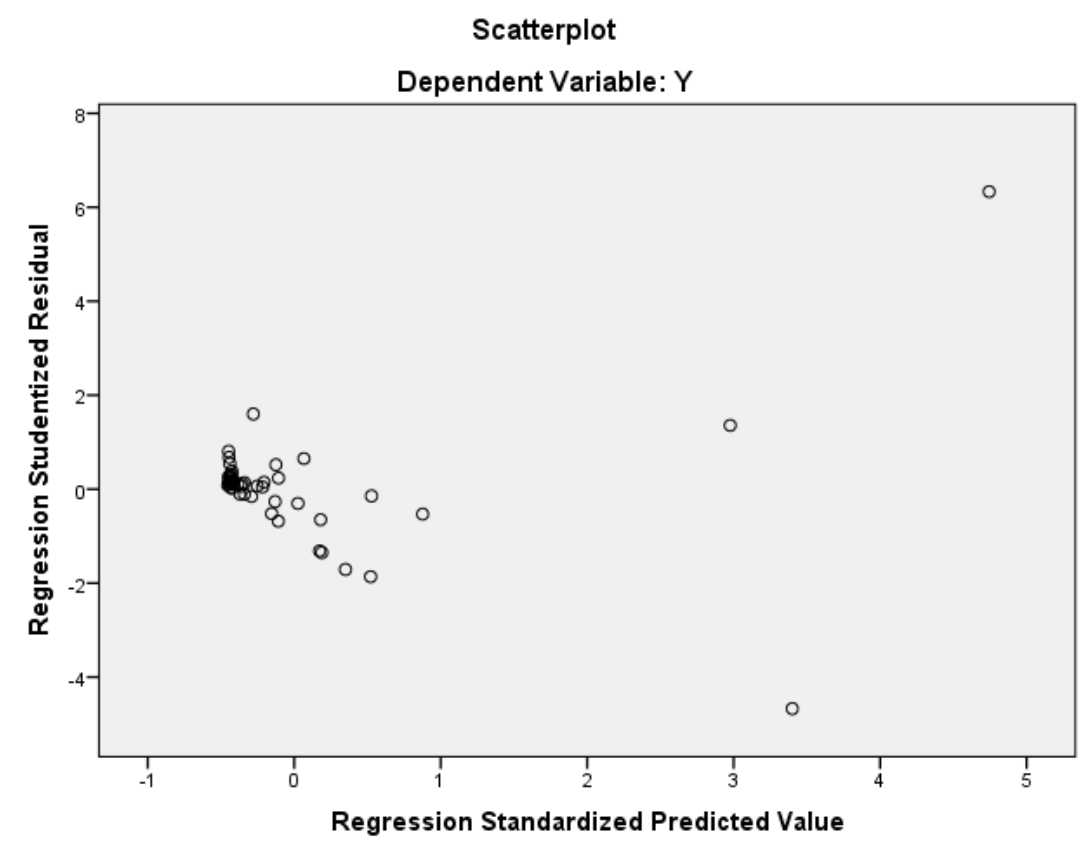

Sumber: Hasil Analisis SPSS, 2019

Gambar 3. Grafik Scatterplots Pada Tarikan Total Kendaraan Pengunjung (smp/jam)

Berdasarkan hasil dari grafik scatterplots dapat diketahui bahwa titik-titik data menyebar di atas dan di bawah atau disekitar angka o. Titik-titik tidak mengumpul pada posisi di atas atau di bawah saja. Penyebaran titik-titik data tidak membentuk pola bergelombang melebar kemudian menyempit dan melebar kembali. Penyebaran titik-titik data tidak berpola. Dengan demikian dapat disimpulkan bahwa tidak terdeteksi masalah heteroskedastisitas pada model, sehingga model regresi yang dihasilkan baik dan ideal untuk melakukan prediksi tarikan perjalanan.

Pada penelitian yang sebelumnya pernah dilakukan yaitu pada titik-titik kawasan perdagangan dan jasa yang tersebar di kota-kota berukuran menengah di Kerala memiliki model tarikan perjalanan $\mathrm{Y}=$ 93,579 
Basuki, Rahayu, Rahmawati/ Jurnal Pembangunan Wilayah dan Kota, Vol. 16, No. 1, 2020, 51-60 Doi: 10.14710/pwk.v16i1.23025

$+\left(0,169 X_{1}\right)-\left(5,653 X_{7}\right)$. Variabel y adalah 10\% perjalanan teratrik simpul komersial, variabel $X 1$ adalah total jumlah karyawan dan $X_{7}$ adalah persentase jumlah kantor di node komersial (George et al., 2007). Interpretasi dari model tersebut dimana perjalanan akan meningkat rata-rata sebesar 0,169 perjalanan per hari untuk setiap penambahan 1 karyawan dan perjalanan akan menurun rata-rata sebsar 5,653 perjalanan untuk setiap kenaikan $1 \%$ dalam persentase kantor di simpul komersial. Penelitian tarikan perjalanan ke mal dengan metode regresi linier berganda memiliki persamaan $Y=167,17+\left(-1,0774 X_{2}\right)+\left(0,0031 X_{4}\right)($ Bali et al, 2017). Variabel yang keluar menjadi model berupa variabel luas tempat parkir untuk kendaraan roda dua, dan luas lantai mal. Persamaan tarikan tersebut pada variabel $X_{2}$ yaitu tempat parkir untuk kendaraan roda dua bernilai negatif, yang artinya setiap ada pengurangan dari luas tempat parkir untuk kendaraan roda dua berkontribusi meningkatkan tarikan perjalanan ke mal.

Penelitian tarikan perjalanan yang dilakukan oleh Mamun, 2014 yang dimana didapatkan model 1: $Y=$ $35,480+0,077 X_{1}+63,136 X_{2}+23,739 X_{3}$, yang dimana variabel yang mempengaruhi tarikan perjalanan orang selama 15 menit ke pusat perbelanjaan berupa luas lantai kotor per 1000 kaki persegi, ketersediaan parkir. Pada model 2 didapatkan persamaan $Y=34,036+0,10 X_{1}+53,984 X_{2}+23,778 X_{3}$, yang dimana variabel yang mempengaruhi tarikan perjalanan orang selama 15 menit ke pusat perbelanjaan berupa jumlah total toko, ketersediaan parkir. Berdasarkan dari persamaan yang diperoleh dapat menunjukkan bahwa tarikan perjalanan orang pada pusat perbelanjaan dipengaruhi oleh banyaknya total toko dan lahan parkir yang tersedia pada pusat perbelanjaan tersebut.

Berdasarkan model tarikan perjalanan kendaraan pengunjung pada kawasan perdagangan dan jasa di Jalan Sukun Raya didapatkan persamaan $Y=0,352+4,998 \mathrm{E}-7 \mathrm{X}_{4}$ untuk memprediksi tarikan perjalanan kawasan perdagangan pada koridor jalan. Pada model tarikan tersebut ditunjukkan variabel yang berpengaruh terhadap tarikan perjalanan kendaraan yaitu variabel omset penjualan toko pada waktu puncak. Persamaan yang didapatkan pada penelitian ini berbeda dengan model persamaan penelitian sebelumnya yang terletak pada variabel bebas yang keluar menjadi model. Karakteristik perdagangan dan jasa skala kecil di Jalan Sukun Raya tarikan perjalanannya tidak dipengaruhi oleh luas area toko, jumlah pegawai maupun luas lahan parkir, tetapi dari besaran omset penjualan yang didapatkan oleh masingmasing toko yang paling mempengaruhi tarikan perjalanan kendaraan pengunjung. Hal ini menunjukkan setiap jenis kawasan perdagangan dan jasa maupun pusat perbelanjaan memiliki faktor pengaruh perjalanan yang berbeda-beda.

\section{KESIMPULAN}

Berdasarkan hasil analisis model tarikan perjalanan pada kawasan perdagangan dan jasa di Jalan Sukun Raya Banyumanik Semarang, dapat disimpulkan bahwa tarikan perjalanan pada kawasan perdagangan dan jasa skala kecil dipengaruhi oleh karakter sosial ekonomi yaitu omset penjualan penjualan dalam bentuk model tarikan $Y=0,352+4,998 \mathrm{E}-7 \mathrm{X}_{4}$. dimana $\mathrm{Y}$ adalah tarikan total kendaraan mobil dan motor pengunjung (smp/jam) dan $\mathrm{X}_{4}$ adalah omset penjualan penjualan (rupiah). Model ini dapat digunakan sebagai masukan dalam perencanaan dan penataan kota khususnya pada kawasan perdagangan dan jasa skala pelayanan kecil untuk mengantisipasi permasalahan transportasi karena berkontribusi pada arus lalu lintas.

\section{PERNYATAAN RESMI}

Penelitian ini didanai oleh Universitas Diponegoro melalui Riset Penerapan dan Pengembangan (RPP) Tahun 2019 Nomor 329-66/UN7.P4.3/PP/2019

\section{DAFTAR PUSTAKA}

Abulebu, Henny Indriyani., et al. (2018). Trip Attraction Model of Central Market in Poso City based on Multiple Linier Regression Model. MATEC Web of Conferences 181, 02008 (2018)

Bali, N. P., \& Zala, L. B. (2017). Trip Attraction Models for Shopping Malls : A Case Study. International Journal for 
Research in Applied Science \& Engineering Technology (IJRASET), 5(IV), 1718-1724.

BPS, 2018. "Kota Semarang Dalam Angka 2018". Semarang: https://semarangkota.bps.go.id/

Currans, Kristina M. (2017). Issues in Trip Generation Methods for Transportation Impact Estimation of Land Use Development: A Review and Discussion of the State-of-the-art Approaches. Journal of Planning Literature, I-II

Datta, Tapan K., et al. (1998). Trip Generation Models for Multiuse Highway Commercial Developments. ITE Journal, pp 24-30

George, P., et al. (2007). "PREDICTION OF TRIP ATTRACTION BASED ON COMMERCIAL LAND USE CHARACTERISTICS". International Journal of Innovative Research in Science, Engineering and Technology An ISO.

Haynes, Kingsley E., \& Fotheringham, A. Stewart. (1984). Gravity And Spatial Interaction Models. Operations Research in Action, pp 9-13

Hutchinson, B. G., 1974. "Principles Of Urban Transport Systems Planning". America: Library of Congress Cataloging in Publication Data

Jayasinghe, A., Sano, K., \& Rattanaporn, K. (2017). Application For Developing Countries : Estimating Trip Attraction In Urban Zones Based On Centrality. Journal of Traffic and Transportation Engineering (English Edition), 4(5), 464476. https://doi.org/10.1016/j.jtte.2017.05.011

Kristoffersson, I., Daly, A. \& Algers, S. (2018). Modelling the attraction of travel to shopping destinations in large-scale modelling. Transport Policy, 68, 52-62

Mamun, M. S., Rahman, S. M. R., Rahman, M. M., Aziz, Y. B., \& Raihan, M. A. (2014). DETERMINATION OF TRIP ATTRACTION RATES OF SHOPPING CENTERS IN ID : TE 024 DETERMINATION OF TRIP ATTRACTION RATES OF SHOPPING CENTERS IN DHAKA CITY. International Conference on Advances in Civil Engineering, (December 2014), 913-917. https://doi.org/10.13140/RG.2.1.2955.7522

Tamin, Ofyzar Z. (2000). Perencanaan \& Pemodelan. 2nd edn. Bandung: ITB.

Sasidhar, K. et al. (2016). "Trip attraction rates of commercial land use: A case study", Indian Journal of Science and Technology, 9(30), pp. 1-5. doi: 10.17485/ijst/2016/v9i30/99245.

Sugiyono. (2014). Metode Penelitian Pendidikan Pendekatan Kuantitatif, Kualitatif, dan R\&D. Bandung: Alfabeta

Yam, B. R. C. M., Whitfield, R. C., \& Chung, R. W. F. (2000). FORECASTING TRAFFIC GENERATION IN PUBLIC HOUSING ESTATES. Journal Of Transportation Engineering, 3(August), 358-361.

Zavattero, David A \& Weseman, Sidney E. (1981). Commercial Vehicle Trip Generation in Chicago Region. Washington District of Columbia, United States: Transportation Research Board. 